\title{
Utopia or Dystopia? Towards a Normative Analysis of Differentiated
}

Integration.

Christopher Lord, ARENA, The Centre for European Studies, The University of Oslo

Address for Correspondence: Christopher Lord, ARENA, Postboks 1143 BLINDERN, 0318 OSLO, christopher.lord@arena.uio.no. Telephone 004722858738. 
Abstract. Few attempts have been made to develop a systematic normative analysis of where differentiated integration may need justification, and by what standards. This paper argues that differentiated integration should be evaluated by a standard of how far it can improve the management of externalities. That is a standard that allows for disagreement at the European level on what values best justify choices between differential and uniform integration. Yet it is also a standard that member states may need to follow if they are to meet their obligations to their own publics to secure values of democracy, freedom and justice. Whether member states also owe one another standards that constrain choices of differentiated integration is then best answered by investigating how far they accord one another rights in the course of managing externalities between themselves. The example of banking union briefly illustrates the last stage of the argument.

KEY WORDS Differentiated Integration; Externalities; Democracy; Justice; Banking Union.

\section{INTRODUCTION}

Is differentiated integration a poison or a panacea? Both views have been forcefully argued. However few attempts have been made to develop a normative analysis of differentiated integration that makes explicit use of philosophical methods to identify where differentiated may need justification, and by what standards. I discuss how that gap might be filled if it is assumed that integration is best justified as a means of managing externalities between European states. I then go on to show how a 'pragmatic philosophical method' can be used to identify norms and standards to which member states commit themselves in the course of using differentiated integration to manage externalities. I end by illustrating that method - and what is to be gained by employing it - through a brief analysis of decisions on banking union. 
The decision to proceed in this way implies two things. First that it is right to give such an important place to the management of externalities in justifying integration. Second that it is also right to define standards in part through an analysis of what actors themselves believe about norms, rather than just base standards on certain rights or values that are assumed to be valid a priori. It will be easier to justify these claims later in the paper if something is first said about existing debates about differential integration.

In a masterful contribution, Rebecca Adler-Nissen (2011) recounts the well-known criticism of differentiated integration that it is a challenge to the authority of the Union; to its telos; to the unity of its policies, laws and institutions; and to any prospect of it developing into a political community based on shared rights and obligations of membership. On the other hand, it might seem unreasonable to insist on a strictly uniform acquis communautaire wherever it can be shown that differentiated integration can better satisfy any needs or values that are believed to justify integration in the first place. In any case, differentiated integration has been transformed from taboo to one of the main sources of pragmatic compromise in EU politics. Reconciling continued integration with a larger and more heterogeneous membership has required the differentiation of integration. So has reconciling the right of some not to participate in unwanted integration with the right of others not to be frustrated from wanted integration.

Indeed, many might feel that there is right and wrong on both sides of the debate: that there must both be some limits to how far member states can cherry pick commitments and some limits to how far the Union can justifiably aim at a uniform set of membership rights and obligations. Maybe, then, there just are inescapable value trade-offs - or even moral dilemmas 
- in differential integration. Yet, if that is so, we need to find some way of evaluating and deciding questions of differential integration in spite of unavoidable normative disagreements about them. To complicate matters further, those disagreements may arise twice over. For, differentiated integration may itself require two distinct forms of justification.

1. On the one hand, any kind of integration -whether differentiated or uniform - presumably requires justification for why particular policies should be made at the European level at all. If, indeed, the main test of normative beliefs is simply one of how well they cohere with one another (Dworkin 2011: 100), some effort has to be made to avoid unjustified inconsistencies between standards used to evaluate differentiated and uniform integration. Those who believe that the one is justified by some value or standard are presumably committed to the other where it can better satisfy the same value or standard.

2. On the other hand, there is one obvious limit to how far justifications for differential integration can just be an extension of justifications for uniform integration. Only differentiated integration begs the further question of whether member states ever owe one another justifications for co-operating in other groups that do not coincide with the membership of the Union. If they do, then differential integration may also require its own quite special form of justification.

This paper argues that it is important to both forms of justification that differentiated integration can help member states manage externalities between themselves. In other words, it can limit harms they would otherwise be able to impose on one another. A focus on the management of externalities does not, however, imply a functionalist justification for differentiated integration that abstracts from disagreements about values. To the contrary, it 
provides just the kind of justification for differentiated integration that allows for disagreements about values. Section 2 shows how a need to manage externalities can be justified by multiple, different values, including the different values that people put on European integration itself. Section 3 shows how managing externalities can provide the first kind of standard sketched above: namely, a consistent standard for evaluating differential and uniform integration, and for making practical choices between the two. Section 4 argues that the further question of whether differentiated integration needs to be evaluated by additional, special standards of its own can be best answered by identifying any norms to which member states commit themselves in the course of their everyday efforts to manage externalities between themselves. I briefly illustrate that 'pragmatic method' through the example of Banking Union.

\section{EXTERNALITIES}

For economists, externalities occur 'wherever production or consumption decisions of some affect the production or consumption of others, other than through market prices' (Begg, Fischer, Dornbusch 1984: 334). Since, however, people do not pay for these external effects of their own decisions, those effects will be over-produced where they are harmful (negative externalities) and under-produced where they are beneficial (positive externalities). Prominent amongst benefits that will be under-provided are public goods, which are 'like a very strong externality' (ibid 352). As Mancur Olson puts it, if 'anyone within a group consumes' them...'they cannot feasibly be withheld from the others within the group' (1966: 14).

Although externalities can only be fully understood with the help of economic theory, they are central to politics. Along with securing rights, the tasks of limiting negative externalities and 
providing public goods are amongst core justifications for political authority. In a section of $A$ Treatise on Human Nature on the 'origins of government', David Hume remarked that 'political society easily remedies' the 'difficulty' that individuals will seek to 'free' themselves of the 'trouble and expense' of providing public goods and 'to lay the whole burden on others' (1978 [1739]: 538-9). Thus political authority can solve the free-rider problem that otherwise constrains the provision of positive externalities in the form of public goods.

Of course some might object that there is something excessively functional in according a central role to externalities in the justification of political power. However, that objection is mistaken. The role of political authority in eliminating negative externalities and providing positive externalities in the form of public goods is a condition for freedom, democracy, equality and justice themselves. A brief survey of how the leading political philosophers of our time have analysed those values demonstrates the point. Philip Pettit (1997) famously argues that freedom cannot just consist of constraints on political authority. For, political authority may itself be needed to prevent powerful private actors from curtailing the freedom of others by arbitrarily dominating them. If, then, freedom is defined as absence of arbitrary domination, it will be incomplete without freedom from polluters, monopolists, or free riders, or, in short, freedom from externalities .

Next, consider how Jürgen Habermas and his followers have understood democracy as an 'ideal of self-determination' in which citizens can 'form and change the terms of their common life together' (Bohman 2007: 2) through laws they give themselves as equals (See also Habermas 1996). Without some means of curbing negative externalities and providing positive externalities, it may be impossible to make key choices at all in matters as fundamental to 'living together with others' as providing security, a functioning system of 
economic exchange or a sustainable eco-system. Hence, a Habermassian view of democracy would likewise seem to presuppose an ability to manage externalities.

Finally, consider how John Rawls (2003: 8-10) argues that the 'primary subject of justice' is the 'basic structure of society - that is, the main political and social institutions and the way they hang together as one system of co-operation'. The basic rules and structures which define how far society approximates to a 'fair scheme of co-operation' plainly form an externality from which no member of a society can easily be excluded. So much so, that, in Rawls' view, any assessment of whether the basic structures of society amount to a fair scheme of cooperation must assume that individuals have to spend their 'whole lives' within them without easy exit options (ibid: 55)

In sum, then, the various standards of freedom, democracy and justice, which contemporary political philosophers consider essential to the justification of political power seem to presuppose an ability to manage externalities through institutions of collective choice. Moreover the most important of those institutions of collective choice - any system of law and any means of generating that law democratically - are themselves public goods and, therefore, positive externalities.

However, politics, democracy, institutions and law are often misaligned with the externalities they are supposed to manage. A particular difficulty in our contemporary world is that the political authority to provide positive externalities and eliminate negative externalities has historically been accumulated by states. Yet, under contemporary conditions of interdependence, states may themselves become a part of the problem. Interdependence increases their ability to impose negative externalities on other states and decreases their 
ability to provide their own citizens with the positive externalities of public goods (Collignon 2003: 88). Indeed, in the case of democratic states, democracy may itself be an incentive to create negative externalities and to free ride on the efforts of other states to provide positive externalities. If voters are purely self-regarding, electoral competition within any one democratic state may only be in 'equilibrium' - in the sense that those competing for power have done everything they can to win votes - at precisely the point that maximises negative externalities and free riding between democracies (Grant \& Keohane 2005).

Of course, international co-operation is one possible solution to these difficulties. In line with Russell Hardin's (1997: 24) observation that collective action problems are both cause and justification for political authority, the role of the European Union in removing externalities has been acknowledged in both positive and normative theories of European integration. Andrew Moravcsik has famously explained both the policies and institutions of the Union as responses to 'international policy externalities' (1993: $485 \&$ 1998: 73). Amongst more normative contributions, Christian Joerges and Jürgen Neyer argue that the Union has developed a framework of both 'law' and of 'political deliberation' that acknowledges that 'no member state can take decisions without causing "extra-territorial" effects on its neighbours'. Hence, in their view, the normative justification for Union law and institutions is an extension of the normative justification of the democratic state itself. European frameworks, as it were, complete the justification for the democratic constitutional state by mitigating one of its remaining 'constitutional defects'; namely, the mismatch between those who are included in its decisions and those who are affected by them (Joerges and Neyer 1997a: 294; Joerges 2006: 789; Joerges 2008: 180). Peter Lindseth likewise argues that European integration has 'disciplined certain negative externalities of national democracy' (2010:1) 
Indeed a commitment to manage externalities is not just common to core values of freedom, democracy and value. It is also common to many different positions of value on the question of European integration itself. There are presumably limits to how far 'euro-enthusiasts' can value associating together with others at the European level on some basis of shared political community whilst continuing to impose negative externalities on them or failing to recognize their shared needs in providing core positive externalities. Yet what is less noticed is that there are also limits to how far it is possible to value member states as self-governing democratic communities without providing for any co-management of externalities at the European level that may be needed for each member state to be meaningfully self-governing. The point is well made in the following argument Richard Bellamy makes for 'repubilican intergovernmentalism':

(The) legitimate state offers its citizens the conditions...for civic freedom. These domestic domestic conditions will insufficient though if the ability of the state to represent its people is undermined by conditions external to it...External interference by other states - be it intended... or an unintended product of negative externalities...limits the capacity of states to represent their peoples in fairly obvious ways...If the domestic policy choices of one state effectively undermine the other, say by one state polluting upstream from another that has tried to reduce pollution, then the behavior of the one reduces the presumptive options of the other in ways that involve illegitimate coercion of one people by another (2013: 504).

\section{A GENERAL STANDARD}

In Justice for Hedgehogs, Robert Dworkin argues that we cannot 'expect agreement from our fellow citizens' on political values and moral convictions in the absence of any 'external standard of truth' against which those qualities can be assessed. Yet, we can 'demand' that others be 'morally responsible' for 'checking their convictions of value against one another'.

Given that 'moral convictions can only be tested by deploying further moral convictions', their validity depends precisely on how well they cohere with one another $(2011: 12,100 \&$ 
120). However, normative standards need to do more than cohere with other normative beliefs. They also need to tell actors how they should decide. Combining these two requirements, this section discusses how far the goal of managing externalities can provide a coherent standard for deciding between differentiated integration and its alternatives of no integration, uniform integration or integration outside the EU. The aim is not to make a case for differentiated integration. It is to merely establish that managing externalities is a worthwhile standard for making and evaluating choices of differentiated integration.

The last section showed how the goal of managing externalities may not itself be a value. But it is a standard that can be coherently adopted by those who otherwise disagree across a range of the different political values - freedom from arbitrary domination, democracy, justice and different conceptions of political community - that are likely to be affected by any kind of integration, whether uniform or differentiated. However, I now want to take the argument one stage further by demonstrating how its value as a standard many actors with different values can employ also gives the goal of managing externalities value as a standard that each individual actor can employ in deciding questions of differential integration.

In exploring how managing externalities can be a valuable standard in this way, I assume that one important question individual actors need to ask themselves in appraising the legitimacy of any form political power - differentiated integration included - is how far it can help them meet obligations they already have (Buchanan 2002 \& 2004). If, as David Beetham puts it, 'legitimacy entails the moral justifiability of power relations' (2013:5), it is hard to see how power could get much more morally justifiable than where it helps those over whom it is exercised meet their own freely-developed moral and political obligations (Habermas 1996: 67). Those who are committed to certain understandings of justice, rights of democracy, are, 
arguably, also committed to accept as legitimate those institutions that are needed to bring them about (Buchanan $2002 \& 2004)$.

Thus the closer we can get to specifying where a particular form of power may even be required - and not just permitted - to meet obligations , the closer we can get to specifying where it might even be illegitimate not to use it. Here, the test of where differentiated integration may even be required is presumably one of how far it may be needed if member states are to meet their own obligations to their own publics. That captures the idea that any form of integration must be legitimate in the 'first instance' (Scharpf 2009) with member states, whilst being ultimately justifiable to individual citizens. The following questions then arise: a) what institutional solutions are available to states seeking to manage externalities between themselves; b) where might differentiated integration within the framework of the EU be the better way of managing externalities between member states and c) where can that give member states a standard for determining where DI is more likely than its alternatives to help them meet their obligations to their own publics?

If asked how a standard of managing externalities might be used to make choices between differentiated integration and its alternatives, economists might answer as follows. In an ideal world, all externalities would be 'optimally internalised' so that each actor pays the cost and receives the benefit of her own behaviour (Pigou 1920). Where, however, the aim is to manage externalities between states, it is vanishingly unlikely that externalities will be optimally internalized by designing each policy so that it is exactly co-extensive with some fixed membership group (Casella \& Frey 1992). Sometimes externalities will be ‘better internalised' where some members of the group are excluded and some non-members are included. 
This begins to tell us where differentiated forms of co-operation may even be required of states. For, if as seen, externalities between states can affect core values of democracy, justice and freedom from arbitrary domination within states, it seems at least arguable that obligations to secure those values internally can both a) oblige states to manage externalities between themselves and b) oblige them to choose the form of co-operation that is the most likely to help them meet their own obligations to their own publics by managing externalities between themselves. However, it is one thing to show that co-operations in groups with varied memberships may be more likely to help states manage externalities that affect their obligations to their own publics. It is another to show that this need have any institutional implications at all. Let alone institutional implications that require member states to ask whether differentiated integration within the institutions of the EU might be the best way of managing externalities that affect their own obligations to their own publics.

Ronald Coase (1960) famously demonstrated that - provided transaction costs are low - actors may be able to manage many externalities by just bargaining between themselves, and without much need for shared institutions. He crucially reached this conclusion without trivialising the problem of managing externalities by pretending that it is somehow free from conflict. To the contrary, he regarded it as inherently conflictual. It is difficult to limit x's ability to impose a negative externality on y without limiting x's freedom; and it is not always obvious that it is fairer to limit x's freedom than it is to protect y against a negative externality. Likewise, there is an irreducible element of conflict and disagreement in providing positive externalities. For, providing public goods usually involves 'one size fits all solutions' which are likely to be much closer to the preferences of some people than others. In 
effect this means that the shared gain from providing public goods does not remove conflict over the allocation of that gain.

Now, there are good reasons to expect groups of states to be able to get quite a long way towards managing externalities by just bargaining between themselves and without much need for shared institutions. Co-operation between states to manage externalities implies a quite different set of relationships to any needed to manage externalities within states. The state has historically needed to be fairly coercive for the simple reason that it has had to have enough sheer, brute force to solve the huge collective action problem of getting millions of individuals to refrain from negative externalities and to contribute to the provision of positive externalities (Olson 1966). In contrast groups of states can be few enough in number to monitor one another and to understand the consequences of lapses in their enforcement for the overall prospects of managing externalities.

Yet there may come a point where transaction costs do require shared institutions. Where there are costs in getting states to disclose what they are really prepared to pay to manage positive or negative externalities (Cornes and Sandler 1986) - or risks that cheating on bargains may get the better of costless forms of self-enforcement - institutions may be needed to propose solutions and enforce commitments

Once, though, institutions are in place, the effects of institutions may themselves need to be included in any evaluation of which solutions may best help states manage externalities that affect their own obligations to their own publics. The costs and benefits of different ways of meeting those obligations may be endogenous to institutions themselves. Co-operations with varied memberships may themselves be better at managing externalities where they are 
developed within institutional frameworks that share norms, information, deliberative forums, law, rights and arrangements for putting options on the political agenda. Two examples illustrate.

Alkuin Kölliker (2001) plausibly argues that of the various ways of enjoying positive externalities, 'club goods' are best suited to being jointly provided by groups of states. Since club goods exclude free-riders anyway, they avoid the contradiction of assuming that groups of states can coerce contributions from single states, which are themselves (supposedly) monopolies of coercion. Nor, in the case of club goods, is there 'rivalry' for benefits. Indeed, there may even be increasing returns, where the use of the good by some increases its value to others. Yet, institutions can themselves use incentives and disincentives to reshape collective action problems so that more of them have the benign characteristics of club goods (Buchanan 1965: 14; Majone 2013).

Stefan Collignon (2003), on the other hand, discusses how externalities may be better managed within shared norms of communication and justification. As he puts it, the economic analysis of externalities assumes exogenous and 'deterministic preferences'. Yet, in complex and fluid settings, preferences may be inconsistent, suggestible or under-determined (Cohen et al 1972). To limit this difficulty, Collignon (ibid) advocates a stochastic model in which actors improve their ability to eliminate negative externalities and provide public goods by communicating and deliberating through shared institutions, all the time up-dating their preferences in the light of new information, including information about the preferences of others, which assume a special importance where the aim is to provide public, rather than private, goods. Trust in reciprocal self-enforcement may likewise be increased where cooperating states acknowledge that they owe one another justifications for their behaviours. 
So, it seems then that a) co-operation in groups of states with variable, rather than fixed, memberships is likely to 'internalise' more externalities; that b) institutions are often needed if externalities are to be managed effectively; and that c), once formed, institutions can themselves develop powers and norms that allow more externalities to be managed. Now differentiated integration within the EU is a distinctive combination of two conditions. It allows some scope for states to co-operate in groups with varied memberships. Yet it also allows them to co-operate within the institutional framework of the Union's enforcement powers, its political agenda, and its norms of communication and justification. Where that combination is more likely than no integration, uniform integration or co-operation outside the EU to manage externalities in ways that help member states meet their own obligations to their own publics, it seems at least arguable that differentiated integration is required of member states.

That begs the obvious question of who should decide everything needed to justify differential integration in that way: the obligations governments owe their own publics; the ways in which those obligations are affected by externalities between states; the circumstances where differential integration within the EU may be better than any alternative at aligning the management of externalities between states with the obligations each state owe their own publics; and whether all that can ever be so important - perhaps to democracy, justice and freedom from arbitrary domination within states - for it even to be illegitimate for states not to employ differentiation integration?

Now it is possible that all these questions can be answered within the democratic politics of each member state. Precisely because managing externalities is a pareto-efficient source of mutual gain, it has a very special normative quality indeed. It allows everyone to co-operate 
for their own reasons of value (Buchanan and Tullock 1962). Provided they can agree for their separate reasons that there is, indeed, a mutual gain to be had from co-operating to manage an externality, each state can decide for itself what obligations to their own publics justify that co-operation. If, indeed, there is a mutual gain to be had, even the distributive effects of any integration - uniform or differentiated - on values within states could, in principle, be compensated out of the 'surplus' each member gains from integration. These paretoimproving implications of taking the management of externalities as a standard are, moreover, especially appealing where co-operation is between democratic states. For, if questions of value can be decided within each member state, they can be decided in political arenas where core conditions for democratic politics - such as political competition, high levels of voter participation, a well-formed public sphere and political community - are easier to secure than at European level.

Yet there may also be limits to how far all questions of obligation can be decided within states. Indeed, where there is little prospect of other governments doing the same, it might seem odd to claim that any one government has an obligation to its own public to select a form of integration that will best help manage externalities between states. In a sense then the obligation is contingent on the behavior of other governments and other demoi. Hence, I said at the start of this section that I would try to demonstrate that the value to each national democracy of taking the management of externalities as a standard for deciding between forms of European integration can be supported by a reasonable expectation that other member states will also find it an acceptable standard. Section 2 argued that it is a standard that can be accepted by those who otherwise disagree about many of the values affected by integration. This section has argued that its broadly pareto-improving character is both a) demoicratic in allowing each demos much scope to decide exactly where differentiated 
integration can be justified by member states' obligations to their own publics and b)

'incentive-compatible' with high levels of co-operation and compliance between states.

\section{SPECIAL STANDARDS AND THE EXAMPLE OF BANKING UNION}

I have argued that differentiated integration should be evaluated by how well it improves the management of externalities between member states in ways that help them meet their own obligations to their own publics. However, a focus on their obligations to their own publics leaves unanswered the question of whether member states also owe one another any rights and obligations that constrain their choices between differential and uniform integration. Quite apart from the suggestion at the end of the last section that obligations governments owe their own publics to adopt any particular form of integration may even be contingent on the behavior of other governments and demoi, some might feel uncomfortable with any suggestion that the obligations member states owe their own publics should be the only test of whether differentiated integration is better than its alternatives. For, EU member states have over time encouraged one another to accumulate shared obligations to shared policies - such as the single market and single currency - which affect life chances and allocations of value in one another's democracies. Moreover, those policies are sometimes without easy exit options. Surely, it might be objected, previous integration has been enough of a common undertaking between member states for each of them to have acquired some element of historic responsibility (For a fuller discussion of national responsibility see Miller 2007) to one another that constrains how far they can just switch between uniform and differential integration without regard for the other democratic peoples of the Union? 
There may also be limits to the claim that all questions of value and obligation should be decided within national demoi whose governments should then bargain the forms of cooperation that best meets their separate obligations to their separate publics. National publics may not always accept that they should have to bargain to avoid all kinds of externality that other member states can impose upon them. Where externalities are so serious that people believe their rights are violated, they do not expect to have to bargain to get solutions. They expect solutions as of right. Moreover, bargaining to manage externalities may only be 'generally' pareto-improving. Once transaction costs upset the comforting assumption that it will always be in the interests of states to co-operate to manage externalities, bargaining cannot guarantee the optimal 'internalisation' of externalities. To the contrary, it may offer no way out of more discriminatory and predatory forms of differential integration between states in which 'ins' collude to impose negative externalities on 'outs' or 'outs' free-ride on 'ins'.

Still, it is at least conceivable that all responsibilities to co-operate with 'due regard for others' could be met through the universal obligations national demoi feel they owe all states or persons who are affected by their actions. Something more is needed to demonstrate that the relationship between EU member states is of a kind that creates special rights and duties (Miller 2002) that then constrain their decisions of differentiated integration. One solution would be to investigate whether member states, in fact, commit themselves to rights and obligations that are specific to the use of differentiated integration to manage externalities between themselves. That may seem like an excessively empirical way of investigating a normative question. Yet, philosophical methods of identifying standards have taken a distinctly empirical turn ever since Wittgenstein and other 'pragmatic philosophers' (Habermas 2003; Brandom 2008; Searle 2010) demonstrated that norms and other meanings are best reconstructed from the commitments actors themselves make in their everyday use of 
language and in their everyday attempts to cope with practical problems. Not only is this the only way of understanding norms if we are to understand them as norms people give themselves. It also acknowledges that norms, as Habermas puts it, are inherently (his emphasis) indeterminate' in that actors need to decide not just on the norms themselves but also on the 'facts' and the 'situations' to which they apply (1996: 219) Thus we may be able to deduce some fairly obvious and general norms from everyday political practice, but still have a lot of further empirical work to do if we are to establish how - and in what circumstances actors commit themselves to apply those norms.

So do member states commit themselves in practice to rights and duties that regulate their use of differentiated integration to manage externalities between themselves? Since only practical examples can answer that question, I briefly use the example of Banking Union to illustrate that it does make sense to investigate rights and duties to which member states appear to commit themselves in coping with specific problems of differentiated integration. Banking Union is a near ideal illustration of the relationship between externalities and differentiated integration. Few other questions have required Union institutions and member states to consider the problems of managing externalities with such urgency and in such depth. Whilst noting that 'over $€ 4.5$ trillion of taxpayers money' has been used to 'rescue banks in the EU' the European Commission has argued that 'shared responsibility for policing the banking sector and intervening in times of crisis...is the only way of limiting negative cross-border spillover effects' (2012a: 3 \& 2012b: 16) or, in other words the negative externalities of deficient national banking regulation.

The difficulty of stabilising the financial system without an agreed framework for managing externalities is clear: where responsibility for the banking system is national but banks are 
international, national authorities have to pay the full costs of bank rescues, even though many of the benefits accrue to other countries. National authorities may, therefore, only insist on sub-optimal levels of bank restructuring and recapitalisation (European Commission 2013: 6). Worse, they are known to have this skewed incentive. That increases the risks of moral hazard on the part of banks, panic on the part of markets, dilatory behaviour on the part of national regulators, and systemic failure on the part of the overall financial system.

Just as Banking Union is a clear case of a policy motivated by a need to solve externalities, so it is a clear case of differentiated integration. It is being developed within a single 'rule-book' of new banking legislation that will apply to all member states. Yet, it also entails differences in how obligations, rights, institutions and structures of political authority will operate across member states. All member states participate in the European Banking Authority (EBA) which will design many technical standards needed to operationalise the single rule-book (OJ L 331/15 15.12. 2010). However, three member states - the Czech Republic, Sweden and the UK - will not participate in the Single Supervisory Mechanism which is being established within the European Central Bank (ECB) to apply the single-rule book. Absence from the SSM also means those countries will not participate in Single Restructuring Mechanism (SRM) which will initiate decisions to restructure or close major financial institutions; nor will they have access to the 'resolution' fund which will back-stop bail-outs that cannot be fully covered by private financial resources or those of 'home' governments. So, all 28 member states will apply the single market legislation on banking regulation; 18 will be in the euro, the SSM and the SRM; 7 will be in the SSM and the SRM, but not in the euro; and 3 will be outside the SSM, the SRM and the euro, but inside the EBA. 
Some have claimed that these differences in participation may even be hard to explain by the distribution of member states' interests in co-operating to manage externalities (Schoenmaker and Siegman 2013). The two countries - the UK and Sweden- that would benefit most from access to a common resolution fund have chosen not to participate in the SSM and SRM. The 'UK would reap 27 per cent of the benefits from improved efficiency of resolution, while its share in the costs would only be 15 per cent. Similarly Sweden would gain 11 per cent of the benefits against a cost share of 2 per cent' (ibid 3)

However I am more interested here in how far member states have had to decide rights questions in the course of deciding Banking Union. The draft SRM legislation stipulates that 'this Regulation respects the fundamental rights and observes the principles recognised in the Charter of Fundamental Rights of the European Union, notably the right to property, the protection of personal data, the freedom to conduct a business, the right to an effective remedy and to a free trial' (European Commission 2013: 29). Likewise, just before the Commission made its proposal on the SRM, the Council unanimously approved single market legislation on banking resolution which stipulates that 'any interference with rights of shareholders and creditors which results from the resolution of credit institutions should be compatible with the Charter of Fundamental Rights' (Council of Ministers 2013). Thus agreement that Banking Union should, indeed, be a relationship governed by rights agreed at the Union level would seem to be accepted by all member states across all categories of those differentially integrated into it. Indeed, the need for at least some agreement on rights has been sufficient even for member states such as Poland and the UK - which are normally eager to limit the extent of their obligations under the Charter for domestic reasons - to accept the Charter as a shared basis for regulating decisions as drastic as the closing and compulsory restructuring of financial institutions. 
Finally, as Amartya Sen (2002) argues, actors may have neither pure normative beliefs about outcomes nor pure normative beliefs about procedures. Thus, the question of how far member states accord one another rights over the use of differentiated integration to manage externalities may need to be investigated twice over, procedurally and substantively. Banking Union provides at least two examples of how procedural rights can be salient in decisions on how uniform and differentiated forms of integration should relate to one another.

First, all 28 member states agreed to establish 'Colleges' to co-ordinate the management of externalities across the European banking system. The Colleges group member states whose banks have cross-holdings or which host financial institutional from other states. Each College is required to conduct joint assessments of those institutions, taking cross-border externalities into account. This introduces an element of 'deliberative supranationalism' (Joerges and Neyer 1997). It acknowledges that those most immediately exposed to negative externalities have a right to a justification for how banking risks are managed in other member states. It provides each national supervisor with the agenda-setting right to raise its concerns about the banking system in other states and have them considered within a common procedure (Bohman 2007).

Second, member states gave much attention to according procedural rights to different categories of 'ins' and 'outs' from Banking Union. They agreed that a double majority - a majority of those member states inside the SSM and a majority of those outside it - will be required where the EBA makes rules applicable to all member states. Likewise they agreed procedural rights - including a mediation panel - for the 7 non-euro countries inside the SSM that face a problem of 'participation without representation' in so far as their banks will be 
supervised by the ECB even though they are not themselves represented on the ECB's General Council (Michel Barnier speech to European Corporate Governance Institute 17 December 2012).

\section{CONCLUSION}

The literature has shown growing interest in analysing European integration as a means of managing externalities between states. What, however, does that imply for how differentiated integration should be evaluated? I have argued here that the need to manage externalities should be treated as a standard that can be accepted by those who otherwise disagree about a range of other values that are affected by European integration. I have further argued that member states should choose differentiated over uniform integration where that better helps them meet obligations they already have to their own publics to secure core political values. That only leaves the question of whether member states also owe one another any special rights and obligations in the choices they make between differentiated and uniform integration. That I have argued is best answered empirically by investigating whether member states accord and specify rights in the course of using differential integration to manage externalities between themselves.

\section{REFERENCES}

Adler-Nissen, R. (2011) 'Opting out of an Ever Closer Union: The Integration Doxa and the Management of Sovereignty', West European Politics 34 (5): 1092-1113.

Beetham, D. (2 $2^{\text {nd }}$ Edition 2013) The Legitimation of Power, Basingstoke: Palgrave.

Begg, D., Fischer, S and Dornbusch, R. (1984) Economics, Maidenhead: McGraw Hill. 
Bellamy, R. (2013) "'An Ever Closer Union Among the Peoples of Europe": Republican Intergovernmentalism and Demoicratic Representation within the EU', Journal of European Integration 35 (5): 499-516.

Bohman, J. (2007) Democracy across Borders from Demos to Demoi, Cambridge MA: MIT Press.

Brandom, R. (2008) Between Saying and Doing. Towards an Analytic Pragmatism, Oxford: Oxford University Press.

Buchanan, A. (2002) 'Political Legitimacy and Democracy', Ethics 112 (4): 689-719.

Buchanan, A. (2004) Justice, Legitimacy and Self-Determination, Oxford: Oxford University Press.

Buchanan, J. (1965) ‘An Economic Theory of Clubs', Economica 32 (125): 1-13.

Buchanan, J. and Tullock, G. (1962) The Calculus of Consent. Logical Foundations of Constitutional Democracy, Ann Arbor, Mi: University of Michigan Press.

Casella, A. and Frey, B. (1992) 'Federalism and Clubs, Towards an Economic Theory of overlapping Political Jurisdictions', European Economic Review 36: 639-646.

Coase, R. (1960) 'The Problem of Social Cost.' Journal of Law and Economics 3 (1): 1-44.

Cohen, M., March, J, and Olsen, J. (1972) 'A Garbage Can Model of Organisational Choice', Administrative Science Quarterly 17 (1): 1-25.

Collignon, S. (2003) The European Republic, Reflection on the Political Economy of a Future Constitution, London: The Federal Trust.

Cornes, C and Sandler T. (1986) The Theory of Externalities, Public Goods and Club Goods, Cambridge: Cambridge University Press.

Council of Ministers (2013) General approach agreed by the June 2013 Ecofin to a proposal for a Directive of the European Parliament and the Council establishinga framework for the resolution of credit institutions etc, Brussels: Council Ministers.

Dworkin, R. (2011) Justice for Hedgehogs, Harvard Mass: Belknap Press of Harvard University Press.

European Commission (2012a) Communication from the Commission to the European Parliament and the Council, A Roadmap towards Banking Union, Brussels: European Commission.

European Commission (2012b) A Blueprint for a deep and genuine economic and monetary union, Brussels: European Commission. 
European Commission (2013) Proposal for a Regulation of the European Parliament and of the Council establishing uniform rules and a uniform procedure for the resolution of credit institutions etc, Brussels: European Commission.

European Council (2012) Towards a Genuine Economic and Monetary Union, Report by the President Herman Van Rompoy, Brussels: European Council.

Grant, R. and Keohane, R. (2005) 'Accountability and Abuses fo Power in World Politics American Political Science Review', American Political Science Review 99(1):29-43.

Habermas, J. (1996) Between Facts and Norms, Cambridge: Polity

Habermas, J. (2003) Truth and Justification, Cambridge: Polity

Hardin, R. (1997) 'Economic Theories of the State' in D. Mueller (ed.) Perspectives on Public Choice, Cambridge: Cambridge University Press, 21-35.

Hume, D. (1978 [1739]) A Treatise on Human Nature, Oxford: Clarendon Press.

International Monetary Fund. (2013) A Banking Union for the Euro Area: Technical Background Notes, Washington: IMF.

International Monetary Fund

Joerges, C. (2006) 'Deliberative Political Processes Revisited: What have we learnt about the Legitimacy of Supranational Decision-Making?' , Journal of Common Market Studies 44 (4): 779-802.

Joerges, C. (2008) 'Working through "Bitter Experiences', in: E.-O. Eriksen, C. Joerges and F. Rödl (eds), Law, Democracy and Solidarity in a Post-National Union: The Unsettled Political Order of Europe, Abingdon: Routledge, 175-92.

Joerges, C. \& Neyer, J. (1997) 'From Intergovernmental Bargaining to Deliberative Political Processes: The Constitutionalisation of Comitology', European Law Journal 3 (3): 273-99.

Köliker. A. (2001) 'Bringing together or driving apart the Union? Towards a Theory of Differentiated Integration', West European Politics 24 (4): 125-51.

Lindseth, P. (2010) Power and Legitimacy: Reconciling Europe and the Nation State, Oxford: Oxford University Press.

Miller, D. (2002) 'Two Ways to Think About Justice', Politics, Philosophy and Economics, 1 (5): 5-28.

Miller, D. (2007) National Responsibility and Global Justice, Oxford: Oxford University Press.

Majone, G. (2005) Dilemmas of European Integraton. The Ambiguities and Pitfalls of Integration by Stealth, Oxford: Oxford University Press.

Moravcsik, A. (1993) 'Preferences and Power in the European Community: A Liberal Intergovernmentalist Approach', Journal of Common Market Studies, 31 (4): 473-524. 
Moravcsik, A. (1998) The Choice for Europe: Social Purpose and State Power from Messina to Maastricht, Ithaca NY: Cornell University Press.

Olson, M. (1966) The Logic of Collective Action, Public Goods and the Theory of Groups, Cambridge: Harvard University Press.

Pettit, P. (1997) Republicanism: A Theory of Freedom and Government, Oxford: Oxford University Press.

Pigou, A . (1920) The Economics of Welfare, London: Macmillan.

Rawls, J. (1993) Political Liberalism, New York: Columbia University Press.

Rawls, J. (2003) Justice as Fairness, A Restatement, Harvard Mass: Belknap Press of University of Harvard Press.

Scharpf, F. (2009) 'Legitimacy in the Multilevel European Polity', European Political Science Review 1 (2): 173-204.

Schoenmaker, D. and Siegmann, A. (2013) Efficiency gains of a European Banking Union, DSF Rearch Paper, Duisenberg: Duisenberg School of Finance.

Searle, J. (2010) The Making of the Social World, The Structure of Human Civilization, Oxford: Oxford University Press.

Sen, A. (2002) Rationality and Freedom, Cambridge MASS: Belknap. 